\title{
Picture of Students' Self-Esteem in Learning Speaking
}

\author{
Yupika Maryansyah and Epi Wadison \\ English Study Program \\ Universitas Muhammadiyah Bengkulu \\ Indonesia \\ yupiedu@gmail.com \\ epiwadison@yahoo.co.id
}

\begin{abstract}
Self-esteem is one of affective factors on students' speaking performance. Accordingly, this study elaborates students' self-esteem while they perform speaking tasks at English Study Program of University of Muhammadiyah Bengkulu (UMB). The current study is set in frame of descriptive study in order to gain indepth qualitative explanation on students' self-esteem. It mainly questions both on types of students' self-esteem and on how the selfesteem description based on gender of students. The study took a massive number of study subjects consisted of students learning speaking from several semesters. The researchers administered questionnaire and interview to collect data of the study. These two instruments were composed based on theories of self-esteem. Data obtained from the two instruments sketched in detail the state of self-esteem of male and female students at Englsih Study Program of UMB. The finding of the study shows that majority of EFL learners at UMB are possessing task self-esteem with the highest percentage of $67 \%$ compared to two other types of self-esteem. In addition, there were no firm difference between male and female learners' self-esteem when they are learning speaking. The result of this study becomes an informative acknowledgement to the field of teaching speaking in term of students' self-esteem when they learn speaking. It also becomes an important information for teachers who teach speaking either at Muhammadiyah University of Bengkulu or at other universities that give speaking subject. In addition, the result also gives broader insight on male and female studensts' self-esteem in learning speaking.
\end{abstract}

Keywords: self-esteem, speaking skill, male student, and female student.

\section{I.INTRODUCTION}

English Study Program of Universitas Muhammadiyah of Bengkulu (UMB) obliges students to possess proficiency on four skills of English (speaking, reading, writing and reading) when they finish their study at UMB. Among the four skills, speaking is a productive skill which demands students' ability to produce utterances on their own way. Speaking is considered to be the most difficult english skill to master because it includes awareness and other communicative considerations. It seems not an easy work for students to learn english speaking. Students need to be accustomed to speak in english. This will be more complicated when students' mother thongue is not english. In addition, students need to pay attention to many related factors like learning environment and affective domain. Learning english speaking in the area like Bengkulu is very challenging since there are not many people can speak in english. In this context, students must have had a very strong determination to learn in order to be an effective and fluent speaker of english.

Accoding to the university statistic most of students at english study program of UMB are from local regencies of Bengkulu province. There are more than $90 \%$ of learners at english study program of UMB are from local regions of Bengkulu. The statistic depiction, at least, may explain students' english educational background and prior knowledge. As broadly known, students from rural areas like regencies in Bengkulu province have less competency than those are from urban areas. The state of students' english mastery and knowledge when they register to be a student at the study program is frequently very low. This condition will affect their development in learning english.

Based on researchers' observation, students' achievement in speaking subject shows no uplifting result. Many students has very little improvement in speaking mastery. The researchers frequently notice students present their undergraduate thesis with poor english speaking skill. Even worse, they sometimes explain their research in indonesian language. When they are asked to elaborate the thesis in english, they admit that they are affraid of making mistake. As the result, they can not deliver good english presentation. This will affect their grade in the examination at the end.

In context of learning speaking, self-esteem is one of personal traits that becomes an influencing factors. it may either make students succeeded or fail to master good english speaking skill. Students with good self-esteem will be confident to utter english sentences and words. They are more active and want to talk everytime. Contrastly, Students who has low self-esteem will be less motivated to speak and tend to have slower development in speaking because they are frequently reluctant to speak, shy, and not sure to say particular words in english.

According to Coopersmith in Brown, self-esteem is personal judgment of worthiness that is expressed in attitudes that individual hold towards themselves [1]. It reflects students' controls toward increase responsibility. People with high selfesteem are not only happy with their success but also happy with their failure [2]. They share optimistic point of view.

Students'self-esteem while learning speaking needs to be studied in deeper sense in order to fully understand the real state of their self-esteem. This is important to do since it is influential in conducting teaching speaking at class. If teacher know that he will be teaching at class that is full of students 
whose self-esteem is in very low level, then he must prepare himself to be equipped with various teaching stragies that may lift up students' self-esteem. A teacher should also aware of selfesteem types possessed by students at class he teach because each of self-esteem type has its own specific characters and specific ways to deal with. For instance, a student with global self-esteem will need long treatment and need more time to adjust with the invironment.

In line with the prior statements, this study explained the state of students' self-esteem in term of what level of selfesteem that students are at english study program of UMB. In addition, the study also studied the gap between male and female students' self-esteem while performing speaking tasks at classes. At the end, the current study also explored reasons beyond students' self-esteem status.

Speaking is one of four skills of english language that mostly become priority to be learned by language learners [3] Students who want to master english completely, can not neglect speaking as one of four importan skills of english. Unless, he or she is only able to write, read, and listen, without having an ability to execute oral communication. Sspeaking skill is the most important skill of English among than the other three, reading, writing, and listening [4]. This is because the main indicator to be called as competent in english language is that a person is able to speak in english, as if the speaking skill involves almost all of language knowledges of a particular language.

Learning speaking is a quite tough and time-consuming process. Accoding to Spolsky, only 5\% of learners of english as a foreign languege can have native-like mastery on speaking, especially for pronunciation and intonation of English [5]. Harmer states that one may be able to speak fluently if both language features and mental processes are involved when he is speaking [6]. In order to speak fluently, a speaker of english must equips himself with a lot of features of english like connected speech, expressive devices, lexis and grammar, and negotion language. A good speaker must be able to employ and recognize modified sounds process like contraction, alision, or assimilation. Paralinguistic elements are also important to support meaning conveyence. Whereas, lexis and grammar are benefitial to enable speaker to use specific expression in english. The negation languages are needed to seek clarification and to exibit the structure of what a speaker is uttering. These all components are called as knowledge of language skills.

An english speaker also must understand some mental processes occuring during speaking, which are language processing, interaction processing, and information processing. The first is taking place when a speaker is dealing with vocabulary in his own brain to produce comprehensible and meaningful utterances. This process involves retrieval of words and phrases from long term memory and then assambled into syntactical form and sequences. Interaction process is a mental process occuring when a speaker is undertanding, listening to others, comprehending what others mean, and knowing when to allow others to speak. So this is a process due to comunicative behavior of a speaker of a language. The last, information processing, is a process dealing with the on-spot respond toward one's intention. A conversation will be effective if both speaker and listener build a smooth spontaneous respond one another. The longer the information is processed the less communicative the conversation will be.

One of affecting factors in learning speaking is affective domain [7]. This domain refers to emotion or feeling. It is an emotional side of human and it may be side by side with cognitive domain. The affective domain of human affects both feeling about our self and feeling about others we in contact to [21]. This domain plays a significant role upon second or foreign language learners in the sense of the ability to be receptive to people they are talking to and the context of communication it self. The domain is also influential in learners readiness to put value to the communicative act involved in interpersonal exchange in communiction.

Self-esteem as the feelings an individual has about him/her self that affect the way he/she views him/her self [8]. Self-esteem is how much value people place on themselves, so it is the evaluative component of self knowledge. Richards and Schmidt notes that self-esteem as a person's judgment of their own worth or value, based on a feeling of efficacy, a sense of interacting effectively with one's own environment [10]. While Self-esteem as value which people place on their own characteristics, abilities and behaviors [11]. Finally, Self-esteem one affective factor that influence human's production among many others [1]. These wide range of statements covers both self-esteem in psychology and self esteem in education sense. All in all, they are implying that self esteem is an affective domain a person has that will affect his/her attitude, behavior and the way he/she deals with life. As a part of affective domain oh human, self-esteem is mostly taking part in most of human's activities including speaking to others.

Three types of self-esteem, namely, global self-esteem, situational self-esteem, and task self-esteem [1]. These types of self-esteem can be jotted down into a level since they are listed in such leveled-like characteristics. The first type is a fixed characteristic in grown up people which cannot be changed only if there is a wide treatment. It is a general or prevailing assessment one makes of one's own worth over time and across a number of situations. This type of self-esteem is a rather fix character of someone that needs long treatments to be changed. Whereas, situational self-esteem refers to one's personal appraisals in certain life situations such as social interaction, work, education and home, or any particular relatively distinctly defined traits such as intelligence, oral ability, athletic ability or personality characteristics like gregariousness, empathy, flexibility to the circumstances and the specific qualities of personalities. The last type, task self-esteem, has relation with the evaluations one makes of particular situations. For instance, in scholar education, task self-esteem is related to only one subject-matter area or athletic situations, or certain skill of sport is assessed in connection with task self-esteem.

Many researchers have done studies on self-esteem. They conducted many studies in order to learn self-esteem in various contexts including the context of English teaching and learning [12, 13]. There are several studies on self-esteem in speaking and oral communication have been conducted. First is the one by Koosha, Ketabi, and Kassaian (2011). They investigated connection between self-esteem, age, and gender in speaking skill on undergraduate EFL students. They found that there was a significant relationship between self-esteem and speaking skill, also there was a reverse relationship between age and speaking skills, and there was not relationship between gender and speaking skill [14]. Aregu (2013) studied the effects of self efficacy, self esteem and gender on performances in speaking tasks among first year university students [15]. The study found that male students exceeded female students in all the variables. He also found that all the variables are interrelated positively. Among these, speaking self-esteem and speaking efficacy were found to have great effects on performance in speaking tasks.

In addition, Milivojevic (2014) examined effect between language speaking with self-esteem, self-efficacy, anxiety, confidence, and stress within secondary language speakers [16]. The result of Milivojevic's study shows that there were significant differences on the outcomes between groups and their use of the English language where beginners show the least self-esteem, confidence, and self-efficacy and more anxiety while the advanced users show the most self-esteem, ${ }_{36}$ confidence 
and self-efficacy and least anxiety with their use and abilities in comprehending and speaking the English language, but there was no difference in stress levels between groups. This study shows that there was a direct correlation between the abilities of a language and its social implications on its use as a secondary language. Naouel (2015) explored relationship between Algerian second year LMD english students' self-esteem and their oral production at the University of Constantine 01, Algeria. He found that that there was a positive relationship between students' self-esteem and their foreign language speaking performance. He noticed that the relationship found affects directly students' level of academic achievement [17].

Recently, Navita (2016) conducted a research to find out relationship between self-esteem and english speaking skill among adolescent learners. Navita revealed that there was a significant and positive correlation between learners' self-esteem and their english speaking skill [18]. The most recent study conducted by Nurdini (2017) who studied communication strategies (CSs) used by EFL students with low and high selfesteem in speaking English. The findings of the study showed that students with low self-esteem employed fewer CSs compared to those with high self-esteem. Students with low selfesteem only used the strategies such as non-linguistic means, appeal for help, and fillers or hesitation device, while the students with high self-esteem level used six kinds of communication strategies such as message abandonment, nonlinguistic means, literal translation, code switching, appeal for help, and fillers or hesitation device [19].

\section{II.METHOD}

This current research is a descriptive study that revealed types of students' self-esteem in performing speaking tasks at english speaking class. It also explained different classification of self-esteem between male and female students. In order to be able to explain the two inquiries, the researchers had distributed questionnaire and conducted interviews to the samples of the study. There were 150 students of English Education Study Program of Universitas Muhammadiyah Bengkulu (UMB) had participated in completing the questionnaire and taken part in the interview. They were from semester I, III, V, and VII of 2016/2017 academic year. There were 31 males and 31 females in first semester, 17 males and 17 females in third, 18 males and 18 females in fifth semester and 9 males and 9 females in seventh semester. Over all semester, there were 75 male and 75 female students were taken as sample of the study.

The instruments used in this study were questionnaire and interview guide. The questionnaire was a set of linkert-like questionnaire related to three types of self-esteem proposed by Brown [1]. There were 60 items on the questionnaire. Each item has been marked with range of 1,2,3,4, and 5. These 60 items comprised of three parts; 20 items for global sefl-esteem, 20 items for situational self-esteem, and 20 items for task selfesteem. At the first part of the questionnaire, researchers focused on examining students' global self-esteem by administering items stating the general self-esteem. In other word, the statements in this part were intended to dig students' global selfesteem related to their whole life activities. Further, the second part of the questionnaire has been aimed to investigate students' self-esteem in situational context. The last part of the questionnaire was adminestered to find out students' self-esteem in term of doing a task. These all statements have been rated as Likert scale does.

In order to crosscheck the data that was obtained from questionnaires, researchers also interviewed several samples. The interview consisted of three pairs of questions which covered the above three levels of self-esteem. Every classification of selfesteem has 2 questions, 1 was a question that used to check participants' affirmation on the class of self-esteem where he or she was classsified, and another one was a question used to check students' negation on the classification of self-esteem where he or she was groupped. This instrument was primarily used to support the data obtained from the questionnaires.

The timing in administering both questionnaire was separated. First, the researchers distributed questionnaire to the students. Soon after the data from the questionnaire has been obtained and the students' self-esteem has been identified, the second instrument, the interview then administered. The phases of data collection was intended to separate students with their self-esteem. Students are classified to have highest percentage on the global self-esteem were asked about their self-esteem to ensure that their self-esteem was really at the global one, so as with the other two. Then, the data from the interview, has been used qualitatively to prove students' self-esteem types. At the end, qualitative difference of self-esteem between male and female students can be determined from students' percentages of self-esteem types and the supporting data from interview.

\section{III.FINDING AND DISCUSSION}

Finding of the study shows that most of first semester students were identified in the task self-esteem classification with $70 \%$ (43 out of 62 students). While situational self-esteem has $20 \%$ (13 out of 62 students), and global self-esteem only has $10 \%$ (6 students of 62 students) who were included into. Just like first semester, the highest percentage in the third semester was also in the task self-esteem classification which reached $70 \%$ (24 out of 34 students). The other two, situational and global selfesteem had excatly the same percentage, 15\% (5 students out of 34 students) for each. The fifth semester was dominated by students with task self-esteem with the percentage of $63 \%$ (22 out 36 students). Also, at this semester, there were $27 \%$ (10 out of 34 students) included into situational self-esteem, and 10\% (4 out of 34 students) were in the global self-esteem classification. In the last semester, which was the seventh semester, 12 students $(70 \%)$ were in the task self-esteem, 2 students (10\%) were in the situational self-esteem, and $4(20 \%)$ were in the global selfesteem. The trend of this finding indicate that majority of students from the four semesters possessed the task self-esteem. This can be seen from the percentages gained. All of the highest percentages were in the task self-esteem classification (table 1).

Table. 1

percentages of students per-semester

\begin{tabular}{|l|c|c|c|c|c|}
\hline smt & $\begin{array}{c}\text { Global } \\
\text { Self- } \\
\text { esteem }\end{array}$ & $\begin{array}{c}\text { Situational } \\
\text { Sefl-esteem }\end{array}$ & $\begin{array}{c}\text { Task } \\
\text { Self- } \\
\text { esteem }\end{array}$ & $\begin{array}{c}\text { Num. } \\
\text { Studen } \\
\text { ts }\end{array}$ & $\begin{array}{c}\text { Total } \\
\text { Percentages }\end{array}$ \\
\hline I & $\begin{array}{c}10 \%(6 \\
\text { students })\end{array}$ & $\begin{array}{c}20 \%(13 \\
\text { students })\end{array}$ & $\begin{array}{c}70 \%(43 \\
\text { students })\end{array}$ & 62 & $100 \%$ \\
\hline III & $\begin{array}{c}15 \%(5 \\
\text { students })\end{array}$ & $\begin{array}{c}15 \%(5 \\
\text { students })\end{array}$ & $\begin{array}{c}70 \%(24 \\
\text { students })\end{array}$ & 34 & $100 \%$ \\
\hline V & $\begin{array}{c}10 \%(4 \\
\text { students })\end{array}$ & $\begin{array}{c}27 \%(10 \\
\text { students })\end{array}$ & $\begin{array}{c}63 \%(22 \\
\text { students })\end{array}$ & 36 & $100 \%$ \\
\hline VII & $\begin{array}{c}20 \%(4 \\
\text { students })\end{array}$ & $\begin{array}{c}10 \%(2 \\
\text { students })\end{array}$ & $\begin{array}{c}70 \%(12 \\
\text { students })\end{array}$ & 18 & $100 \%$ \\
\hline Total & $\begin{array}{c}19 \\
\text { students }\end{array}$ & 30 students & $\begin{array}{c}101 \\
\text { students }\end{array}$ & $\begin{array}{c}150 \\
\text { studen } \\
\text { ts }\end{array}$ & $100 \%$ \\
\hline
\end{tabular}

As a whole finding, from the total of students from all semesters (150 students), $67 \%$ students or 101 students were found to have task self-esteem classification. Meanwhile, $20 \%$ of students (30 students) have been included into the situational self-esteem classification. The other 19 students (13\% out of 150) were at global self-esteem group (table2). 
Table. 2

total percentages of students self-esteem

\begin{tabular}{|c|c|c|c|}
\hline No & Self-esteem & Percentages & Number of students \\
\hline 1 & $\begin{array}{ll}\text { Global } & \text { Self- } \\
\text { esteem } & \end{array}$ & $13 \%$ & 19 \\
\hline 2 & $\begin{array}{l}\text { Situational Sefl- } \\
\text { esteem }\end{array}$ & $20 \%$ & 30 \\
\hline 3 & Task Self-esteem & $67 \%$ & 101 \\
\hline \multicolumn{2}{|c|}{ Total } & $100 \%$ & 150 \\
\hline
\end{tabular}

Regarding the students' gender and the classification of self-esteem, it was found that more male students have global self-esteem than female. Among 19 students who were at global self-esteem classification, 11 of them are male, and 8 were female. Furthermore, the situational self-esteem has got the same portion of number of male and female students, which was 15 students. It was also found that there were more female students found to have task self-esteem classification than male, 52 students for female students and 49 for male students (table 3 ). It can be seen that male students dominated in the global selfesteem. Both male and female students had the same portion in the situational self-esteem. And, in contrast with the global selfesteem, the task self-esteem has been dominated by female students.

Table 3

portion of male and female students' self-esteem

\begin{tabular}{|c|c|c|c|c|c|}
\hline \multirow[t]{2}{*}{ No } & \multirow[t]{2}{*}{ Self-esteem } & \multicolumn{4}{|c|}{ Portion of male and female students Self-esteem } \\
\hline & & $\begin{array}{l}\text { Percentage } \\
\text { from total } \\
\text { students } \\
\text { self-esteem }\end{array}$ & Male & Female & Total \\
\hline 1 & $\begin{array}{c}\text { Global Self- } \\
\text { esteem }\end{array}$ & $13 \%$ & 11 & 8 & 19 \\
\hline 2 & $\begin{array}{r}\text { Situational } \\
\text { Sefl-esteem }\end{array}$ & $20 \%$ & 15 & 15 & 30 \\
\hline 3 & $\begin{array}{c}\text { Task Self- } \\
\text { esteem }\end{array}$ & $67 \%$ & 49 & 52 & 101 \\
\hline Tota & & $100 \%$ & 75 & 75 & 150 \\
\hline
\end{tabular}

In supporting the data obtained from the questionnaires, the data obtained from interview was properly benefitial. The researchers asked 15 students to attend interview on the three classifications of self-esteem. 5 students were taken from the students whose questionnaire result were in global self-esteem, 5 were from situational self-esteem, and another 5 were from task self-esteem. In order to check their self-esteem classification while performing speaking tasks, they were asked about their behavior. All of the 5 students those are from the global selfesteem stated that they tended to be reluctant to do many things, especially something they do not completely understand. Similarly, the 5 students from situational self-esteem group who were asked whether they are nervous or not if they are asked to speak publicly, said that they were mostly affraid of speaking in public. They also added that they were nervous even they were about to speak in Indonesian language in font of audiences. The other 5 students from task self-esteem group mentioned that they have an anxiety of mispronuncing english words in performing speaking tasks at class.

This scheme of finding explains implies that most of students' self-esteem were at task self-esteem. This indicates that students are having a kind of self-esteem related to one specific subject matter (Brown, 2007). In learning of speaking skill point of view, this kind of self-esteem could be positive to support speaking achievement. Students could take benefit of self-esteem if it is high. So this is a good sign for lecturers who teach speaking. They must be able to create supporting environment to encourage students to utilize their task self-esteem.

The key point is how to make the task in speaking subject enjoyable and exciting for students. It is also hoped that in the context of second language acquisition and learning speaking at class, learners can encourage themselves to perform better in their oral performance by enhancing their self-esteem related to their task. Such enhancement will help them have better conceptions of their abilities in their oral skills.

As can be seen in the current study's finding, female students had dominated the task self-esteem classification. Although studies on gender in foreign language learning show inconsitent result, task self-esteem possessed by female students might be the trigger of their domination in learning. Taks selfesteem allows them to be more confident in learning speaking. In other hand, male students dominated the global self-esteem. This is an alert for people involved in teaching speaking at UMB to make bigger effort to deal with these students as global selfesteem is tightly related to the humans' general temperament or personality. As Robins, Norem and Cheek (1999) mention that a person's consistent pattern of thought, feeling, and behaviour should influence how they feel about them selves [20]. Additionally, this type of self-esteem needs long range of treatment to change [1].

\section{IV.CONCLUSION}

Learning speaking in foreign language context is not a simple process. There are many factors affecting such process. One element that can not be neglegted is affective domain of human. People involved in the process of speaking teaching and learning must be aware of self-esteem as a part of affective side of EFL learners. This study depicted the state of self-esteem at english study program of Universitas Muhammadiyah Bengkulu, at Bengkulu Province, Indonesia. This reseach found that majority of EFL learners possessed task self-esteem while they are performing speaking tasks at class. One thing that can be highlighted in this sense, which is majority of learners have a good chance to be success in learning speaking because they adopted a fit self-esteem on performing their taks. Another thing that can be underlined is the differentiation on male and female EFL learners' self-esteem. This picture of self-esteem will challenge speaking lecturers to be able to teach speaking to students with diversity on self-esteem level. However, the lecturers of speaking at UMB are required to boost supporting environment in learning by utilizing any resources they have.

\section{References}

[1] Brown, H. D. Principles of language learning and teaching. (4th Ed.) NY: Pearson Education LTD. 2007.

[2] Brown, J. D., \& Marshall, M. A. The three faces of selfesteem. Self-esteem: Issues and answers. Ed. M. Kernis: New York: Psychology Press. 2006.

[3] Richard, Jack C. Teaching Listening and Speaking from Theory to Practice. New York: Cambridge University Press. 2008.

[4] Ur, Penny. A Course in Language Teaching Practice and Theory. Cambridge: Cambridge University Press. 1991.

[5] Spolsky, B. Condition for Second Language Learning. Oxford: Oxford University Press. 1989.

[6] Harmer, Jeremy. The Practice of English Language Teaching. Essex: Pearson Education Limited. 2001.

[7] Oxford, R. L. Language Learning Strategies: What Every Teacher Should Know. New York: Newbury House Publishers. 1990.

[8]Schwalbe, M.L., \& Staples, c.L. (1991). Gender differences in sources of self-esteem. Social Psychology Quarterly, 54, 158-168.

[9] Baumeister,Roy F. et.al. "Does High Self-Esteem Cause Better Performance, nterpersonal Success, Haspiness, Or 
Healthier Lifestyles". Psyhcological Science in Public Interest. 4.1. (2003). 1-39.

[10] Richards J. C. \& Schmidt R. Dictionary of language teaching and applied linguistics (3rd ed.). Essex: Pearson Education Company. 2002.

[11] Woolfolk, A. Educational psychology (9 ed.). Essex: Pearson Education, Inc. 2004.

[12] Kamarzarrin, H. A study of self-esteem third grade students of governmental and private high schools of Dezful. M.A thesis.Shiraz University of Iran. 1994.I

[13] Carter, R., \& Nunan, D. The Cambridge guide to teaching English to speakers of other languages. Cambridge: Cambridge University Press. 2001.

[14] Koosha, B., Ketabi, S., \& Kassaian, Z. "The Effects of SelfEsteem, Age and Gender on the Speaking Skills of Intermediate University EFL Learners". Theory and Practice in Language Studies. 1.10. (2011).

[15] Aregu, Bekele birhanie. "Self-Efficacy, Self-Esteem and Gender as Determinants of Performance in Speaking Tasks". Journal of Media and Communication Studies. 5.6. (2013). 64-71.

[16] Milivojevic, Vucas. Examining the Relationship Between: English as Second Language on Self-esteem; self-efficacy, Confidence, Stress and Anxiety. BA thesis. Dublin Business School, Dublin. 2014.

[17] Naouel, Miss B. "The Role of Foreign language Learners' Self-esteem in Enhancing Their Oral Performance". Express; an International Journal of Multi Disciplinary Research. 2.2.(2015).

[18] Navita. "Role of Self-esteem in English Speaking Skill in Adolescent Learners". Research Journal of English Language and Literature (RJELAl). 4.4. (2016). 216-220.

[19] Nurdini, Rahmi A. "Communication Strategies Used by EFL Students with High and Low Self-esteem". Journal of ELT Research. 2.1. (2017). 9-14.

[20] Robins, R., Norem, J., \& Cheek, J. Naturalizing the self. Handbook of personality: Theory and research. Ed. L. Pervin \& O. John. New York: Guilford Press. 1999.

[21] Brown, H.D. Principles of Languagel Learning and Teaching (fourth edition). NY: Addison Wesley Longman, Inc. 2000. 